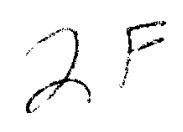

PNL-10146

UC-900

\title{
Final Project Report \\ Dual Shell Pressure Balanced Reactor Vessel
}

\author{
R. J. Robertus \\ A. G. Fassbender \\ October 1994 \\ Prepared for the U.S. Department of Energy \\ under Contract DE-AC06-76RLO 1830 \\ Pacific Northwest Laboratory \\ Operated for the U.S. Department of Energy \\ by Battelle Memorial Institute
}




\title{
DISCLAIMER
}

This report was prepared as an account of work sponsored by an agency of the United States Government. Neither the United States Government nor any agency thereof, nor Battelle Memorial Institute, nor any of their employees, makes any warranty, expressed or implied, or assumesany legal liability or responsibility for theaccuracy, completeness, or usefulnessof any information, apparatus, product, or process disclosed, or represents that its use would not infringeprivately owned rights. Referenceherein to any specific commercial product, process, or serviceby trade name, trademark, manufacturer, or otherwisedoes not necessarily constitute or imply its endorsement, recommendation, or favoring by the United States Government or any agency thereof, or Battelle Memorial Institute. The views and opinions of authors expressed herein do not necessarily state or reflect those of the United States Government or any agency thereof.

\author{
PACIFIC NORTHWEST LABORATORY \\ operated by \\ BATTELLE MEMORIAL INSTITUTE \\ for the \\ UNITED STATES DEPARTMENT OF ENERGY \\ under Contract DE-AC06-76RLO 7830
}

Printed in the United States of America

Available to DOE and DOE contractors from the

Office of Scientific and Technical Information, P.O. Box 62, Oak Ridge, TN 37831; prices available from (615) 576-8401. FTS 626-8401.

Available to the public from the National Technical Information Service, U.S. Department of Commerce, 5285 Port Royal Rd., Springfield, VA 22161. 


\section{Final Project Report}

\section{Dual Shell Pressure Balanced Reactor Vessel}

R. J. Robertus

A. G. Fassbender

October 1994

Pacific Northwest Laboratory

Richland, Washington 99352 


\section{Dual Shell Pressure Balanced Reactor Vessel}

Staff exchanges are intended to facilitate communication and collaboration among scientists and engineers at Department of Energy (DOE) laboratories, in U.S. industry, and academia. Funding support for exchanges is provided by the DOE, Office of Energy Research, Laboratory Technology Transfer Program. The exchanges offer the opportunity for the laboratories to transfer technology and expertise to industry, gain a perspective on industry's problems, and develop the basis for further cooperative efforts through Cooperative Research and Development Agreements (CRADAs) or other mechanisms.

\section{Introduction}

The Department of Energy's Office of Energy Research (OER) has previously provided support for the development of several chemical processes, including supercritical water oxidation, liquefaction, and aqueous hazardous waste destruction, where chemical and phase transformations are conducted at high pressure and temperature. These and many other commercial processes require a pressure vessel 'capable of operating in a corrosive environment where safety and economy are important requirements. Pacific Northwest Laboratory (PNL) engineers have recently developed and patented (U.S. patent 5,167,930 December 1, 1992) a concept for a novel Dual Shell Pressure Balanced Vessel (DSPBV) which could solve a number of these problems. The technology could be immediately useful in continuing commercialization of an R\&D 100 award-winning technology, Sludge-to-oil Reactor System (STORS), originally developed through funding by OER.

Innotek Corporation is a small business that would be one logical end-user of the DSPBV reactor technology. Innotek is working with several major U.S. engineering firms to evaluate the potential of this technology in the disposal of wastes from sewage treatment plants. PNL entered into a CRADA with Imotek to build a bench-scale demonstration reactor and test the system to advance the economic feasibility of a variety of high pressure chemical processes.

Hydrothermal processing of corrosive substances on a large scale can now be made significantly safer and more economical through use of the DSPBV. Hydrothermal chemical reactions such as wetair oxidation and supercritical water oxidation occur in a highly corrosive environment inside a pressure vessel. Average corrosion rates from 23 to 80 mils per year have been reported by Rice (1994) and Latanision (1993). The actual observed corrosion is often uneven, and pitting is sometimes observed. In addition, 316 stainless steel, Inconel 625, and Hastelloy C-276 have exhibited stresscorrosion cracking when used as pressure vessels for hydrothermal processes. Differential thermal expansion, uneven corrosion, pitting and stress-corrosion cracking limits the use of lined vessels. Undetected breached linings could lead to prolonged hidden corrosion of the pressure vessel. The DSPBV vessel eliminates costly choices between strength and corrosion resistance; between temperature, pressure, and vessel life; and between safety and effective operation and maintenance. This new technology combines ordinary steel, specialty metal alloys, and ceramics in a unique, patented design to meet the challenges of corrosive chemistry in pressurized processes. 
The DSPBV uses a separate inner shell, inside a pressure vessel insert that fits close to the wall of the outer shell of the pressure vessel. The insert is constructed of a metal or alloy such as Inconel, Hastelloy, zirconium, titanium, tantalum, titanium-tantalum, titanium-niobium, or a ceramic such as alumina. A pressure-transfer fluid, such as Syltherm $800^{\circ}$ or water, is placed in the annulus between the pressure vessel and the specialty material insert or working reactor. The pressure-transfer fluid is kept physically separate and in hydrostatic equilibrium with the fluid entering the reactor. The pressure balancing is achieved by an external piston or by allowing the insert to change volume to respond to pressure and thermal forces. Because the fluid pressure is balanced on both sides of the insert, the insert is not under significant stress, so stress-corrosion cracking is minimized. The insert's thickness is determined by corrosion potential rather than strength; thus, it must only be thick enough to support its own weight and act as an envelope to separate the corrosive reactants from the steel pressure vessel. The DSPBV design provides adequate space between the insert and the pressure vessel to allow for any degree of differential thermal expansion. The strength and corrosion resistance specifications of the pressure vessel are decoupled from the specifications of the insert. Specialty metal pressure vessels are expensive, not only because a large amount of metal must be used for strength, but because they are challenging to weld, fabricate, and certify. The patented DSPBV design combines steel and specialty metals to let designers select the optimum materials for corrosion resistance of the inner shell separate from pressure vessel considerations.

The outer shell, or pressure vessel, is constructed of carbon or chrome-moly steel components such as extra heavy pipe and standard 2500 pound class steam fittings. Carbon steel and chrome-moly steel are much less costly to buy and fabricate into pressure vessels than are exotic alloys and specialty metals.

While the pressure-transfer fluid balances the pressure, its electrical properties are continuously monitored to ensure the integrity of the insert. A significant change in conductivity of the pressuretransfer fluid alerts operators to a breach of the inner reactor so it can be replaced before the steel pressure vessel corrodes. The ability to continuously monitor the integrity of the working reactor is a fundamental safety advance for this industry.

The DSPBV working reactor unit is designed to monitor, protect, and preserve the integrity of the steel pressure vessel. The working insert is designed for easy replacement as needed. The removable insert allows users to take advantage of the latest advances in material science in a cost-effective manner.

\section{Purpose/Objectives}

The objectives of the proposed work were to

design a prototype DSPBV

- design the DSPBV support equipment

- demonstrate the operability of the DSPBV

- utilize the successful demonstration to secure additional funding for continued development. 


\section{Summary of Activities}

The dual shell pressure-balanced reactor vessel (DSPBV) was sized to process $10 \mathrm{gal} / \mathrm{hr}$ of hazardous waste at up to $750^{\circ} \mathrm{F}\left(399^{\circ} \mathrm{C}\right)$ and $5000 \mathrm{psia}(34.5 \mathrm{MPa})$ with a residence time of 10 minutes. A stress analysis of the reactor vessel indicated the design has a good safety margin for the chosen operating conditions. The first prototype reactor was purchased by Innotek Corporation and built by Engineered Pressure Systems Inc. (a division of National Forge) in Andover, Massachusetts. It was built as a certified ASME pressure vessel. The vessel dimensions resulting from this design and fabrication activity are shown in Figure 1.

Supporting equipment and instrumentation was identified, and specifications were documented. Preliminary blueprints have been prepared for the complete reactor system. The reactor system was designed as a skid mounted package unit which could be moved to industrial sites after proof-ofprinciple experiments are completed at PNL.

An internal safety review of the design package was completed by Safety and Quality Assurance staff at PNL.

\section{Reactor Design}

The DSPBV selected operating pressure (3500 psia [24.1 MPa]) and temperature $\left(700^{\circ} \mathrm{F}\left[371^{\circ} \mathrm{C}\right]\right)$ were based on literature references (Shaw et al. 1991 and Dell Orco et al. 1992) for laboratory-scale results of Supercritical Water Oxidation (SCWO). The 10-minute residence time was a compromise based on these reports. Some wastes can be destroyed in a few seconds and others may require 30 minutes. The $10 \mathrm{gal} / \mathrm{hr}(36 \mathrm{~L} / \mathrm{hr})$ was considered sufficient to provide good data for at least a future pilot-scale version of the concept.

The DSPBV uses a thick steel outer shell as the pressure boundary and a thin disposable inner liner which can be made from corrosion resistant alloys appropriate for the chemicals being processed. The shell and the inner liner are separated by heat transfer fluid (used here as a pressure transfer fluid). The pressure between the heat transfer fluid and the reacting fluid is maintained by an external piston that remains at ambient temperature. A pressure compensator is needed because the heat transfer liquid $\left(\right.$ Syltherm $\left.800^{\circledR}\right)$ expands about $65 \%$ in volume between ambient and $750^{\circ} \mathrm{F}\left(399^{\circ} \mathrm{C}\right)$.

A second disposable inner liner is used as a flow diverter so reactants enter and products leave the same end of the vessel. The disposable inner liners allow the study of corrosion characteristics of many materials such as Inconel, Hastelloy, zirconium, titanium, titanium-tantalum, or titanium-niobium alloys for a fraction of the cost of building a complete reactor out of these materials. The design is inherently safer than metal clad vessels because sensors in the heat transfer fluid will detect when the corrosion-resistant alloy has been breached. Metal clad vessels have no simple warning system and penetration of the cladding generally results in rapid deterioration of the parent metal.

Figure 2 shows a sketch of the fundamental pieces involved in the pressure balanced piston idea. Other options were studied but rejected for either time or money considerations. These concepts included 1) a bellows, 2) a sliding o-ring seal, and 3) the balancing piston with a stationary o-ring seal (instead of welds used in the final design). 


\section{Support Equipment}

The supporting equipment (see the Appendix) was grouped into six categories for purposes of designing transportable modules. Secondarily the modules grouped equipment to enhance safe operation. The modules were

- the main reactor and pressure balancing piston

- hazardous waste feed supply tanks and pump

- Syltherm supply tanks and pump

- high pressure oxygen supply system

- pressure let-down equipment

- containment vessels.

Optional modules are shown in the Appendix for bottled oxygen and bottled nitrogen. The nitrogen is a purge gas for feed and let-down vessels as well as the containment vessel. The containment equipment is designed to capture all the reactor fluids in the event of an over-pressure, cool them to $150^{\circ} \mathrm{F}$ or lower, and keep them in a nitrogen purged containment vessel until a final disposal plan is approved. Originally the equipment was designed to handle a variety of wastes. The nitrogen manifold and containment vessels were needed to handle some Department of Defense munitions wastes which can be unstable in the presence of air. Funding is still being sought from the Navy to demonstrate destruction of some of their munitions wastes.

Figure 3 shows schematically a picture of existing equipment that will be used in the follow-on work to prove that the DSPBV really works. Waste materials will be more benign (e.g., sewage sludge effluent) and can be processed using simpler safety controls.

\section{Significant Accomplishments}

- A transportable system using the DSPBV has been designed.

- Preliminary blueprints have been developed for the entire system.

- The first prototype reactor vessel has been built and delivered to PNL.

- Support equipment was identified at PNL to perform initial testing.

- Follow-on funding has been obtained to test the reactor vessel.

\section{Significant Problems}

Funding levels were insufficient to build the transportable system designed in this effort. Using existing equipment will limit the range of conditions which can be investigated.

\section{Industry Benefits Realized}

This collaborative research program succeeded in building the first prototype Dual Shell Pressure Balanced Vessel. We believe the concept can be commercially successful on a larger scale and can be 
fabricated much less expensively than current practice. Simultaneously the concept can enhance safety and operability of many emerging high pressure chemical processes.

The adoption and commercialization of a broad range of new high pressure chemical technologies will be enhanced by the development of the DSPBV. The potential market for this vessel is far reaching particularly in environmental management. Specific technologies include supercritical fluid extraction or oxidation, wet air oxidation, hydrothermal materials processing, and sewage sludge to oil conversion.

\section{Follow-on Work}

The design and fabrication of the first DSPBV have led to funding from DOE's Environmental Management office to conduct the proof-of-principle experiments in its SCWO program.

A spin-off CRADA has also been funded to help perfect the leak detector design which is a critical part of the safety instrumentation. Innotek is a participating partner in both activities.

Existing hydrothermal equipment at PNL will be modified and used to conduct the proof-ofprinciple tests for the SCWO program.

Testing of this unit will bridge the gap between science in the laboratory and private industry utilization.

\section{References}

Dell'Orco, P. C., B. R. Foy, J. M. Robinson, and S. J. Buelow. 1992. Hydrothermal Treatment of Hanford Waste Constituents. Los Alamos National Laboratory Report LA-UR-92-2508. Los Alamos National Laboratory, Los Alamos, New Mexico.

Latanision, R. M., and R. W. Shaw. 1993. Corrosion in Supercritical Water Oxidation Systems. Workshop Summary, MIT, MIT-EL 93-006.

Rice, S. F. et al. 1994. Supercritical Water Oxidation of Colored Smoke, Dye, and Pyrotechnic Compositions. Sandia Report, SAND94-8209, UC-402. Sandia National Laboratories, Albuquerque, New Mexico.

Shaw, R. W., T. B. Brill, A. A. Clifford, C. A. Eckert, and E. U. Franck. 1991. "Supercritical Water: a Medium for Chemistry," C\&EN, pp. 26-38, December 23, 1991. 


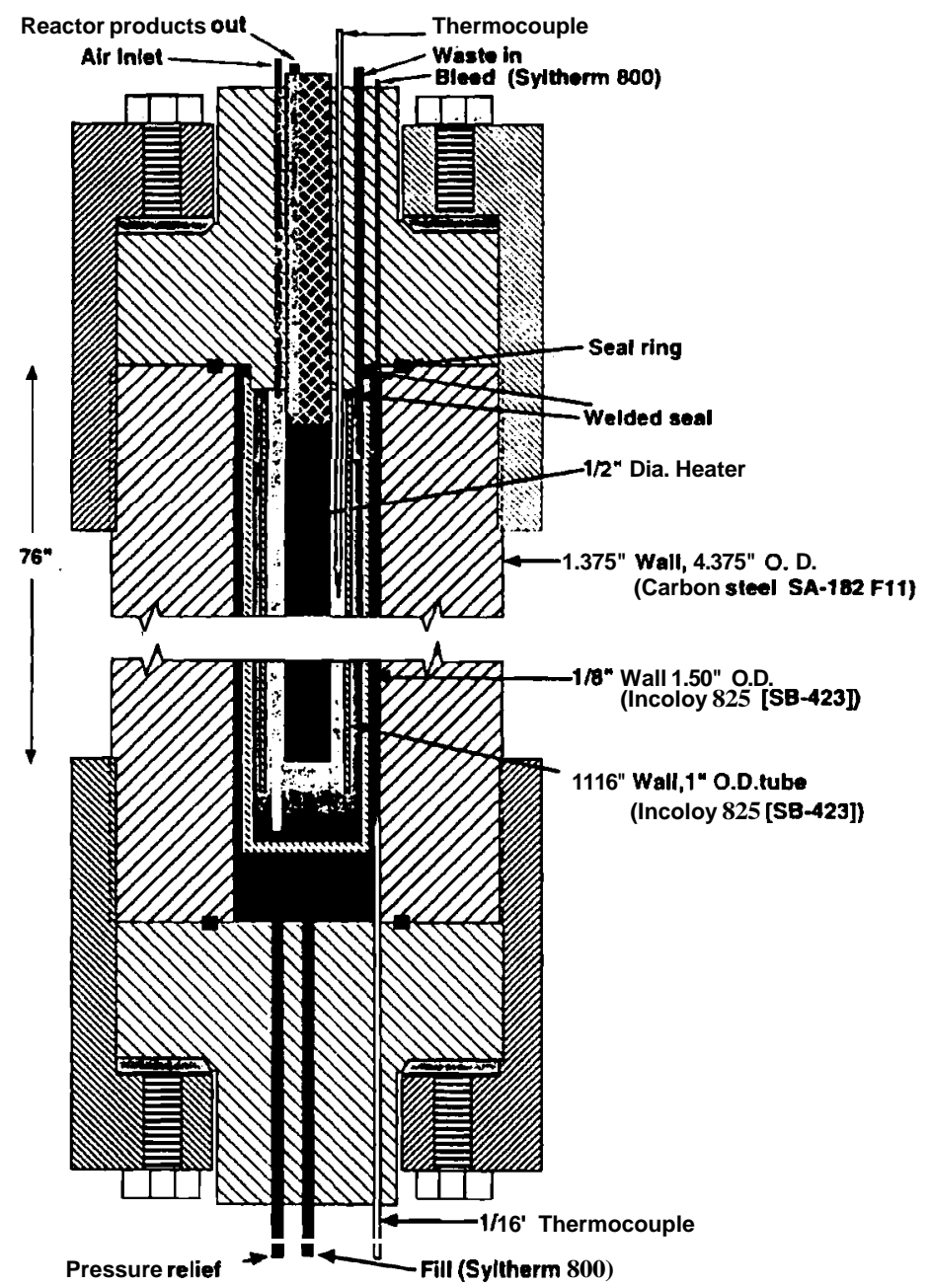

Figure 1. Sketch of Dual Shell Pressure Balanced Vessel 


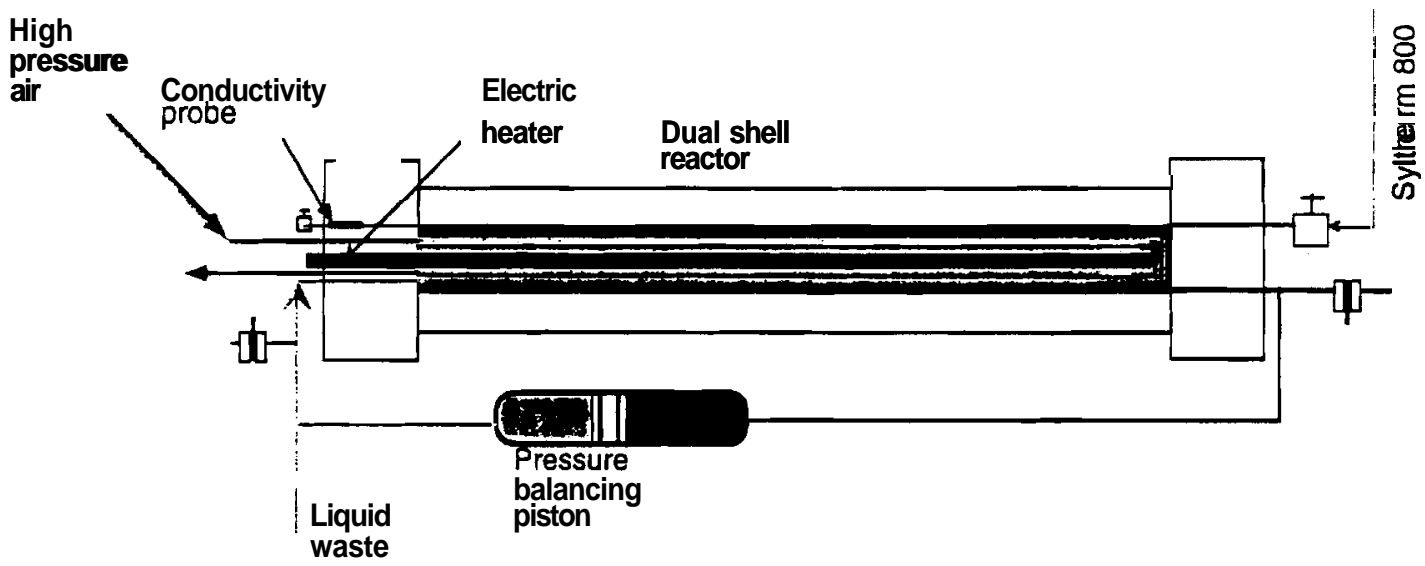

Figure 2. Reactor Vessel with Pressure Balancing Piston 


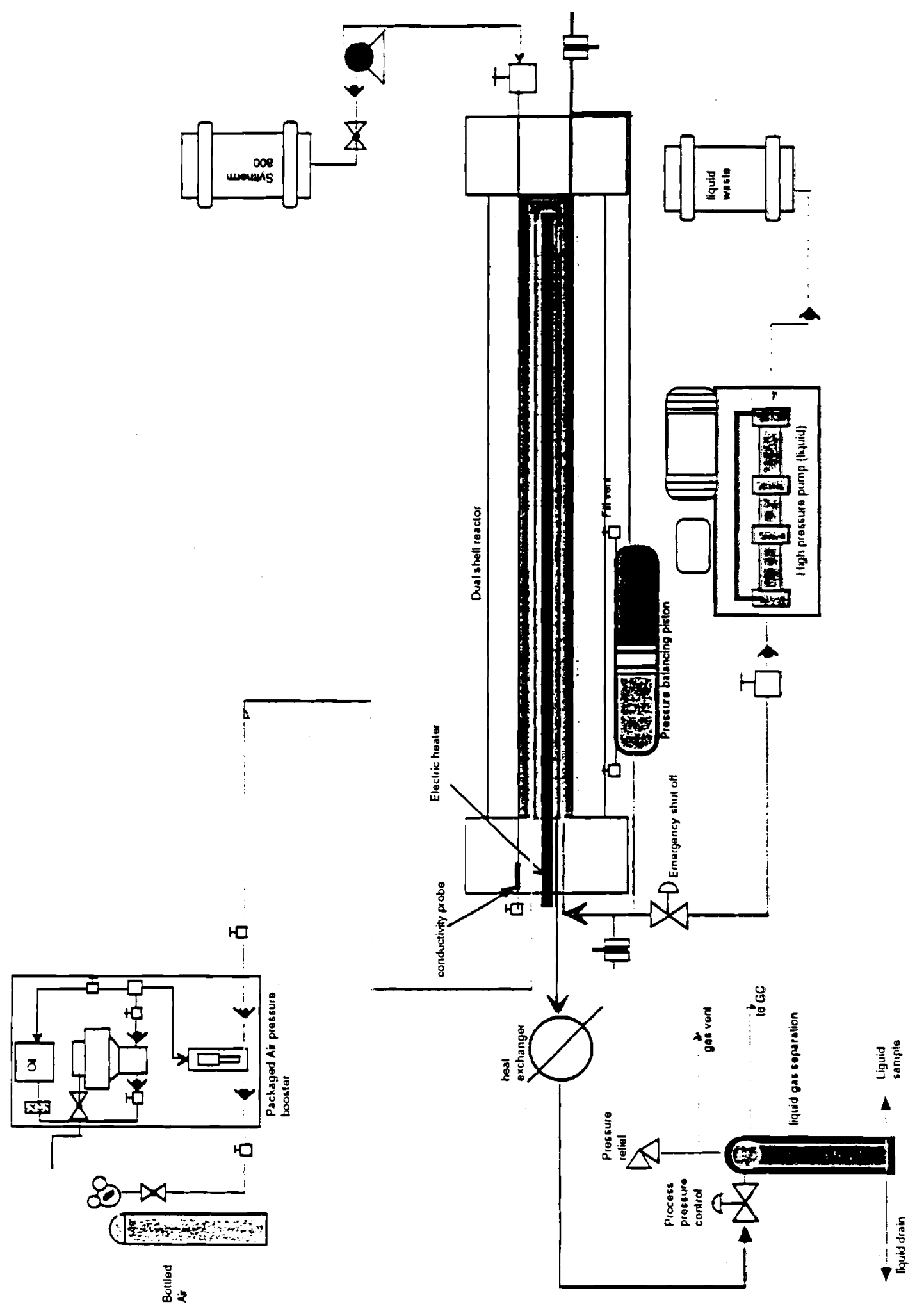

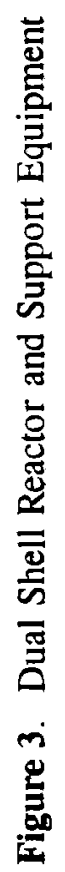




\section{Appendix}

Preliminary Equipment List and Drawings

for

Dual Shell Pressure Balanced Vessel

and

Supporting Equipment 


\section{Appendix}

\section{Preliminary Equipment List and Drawings \\ for \\ Dual Shell Pressure Balanced Vessel \\ and \\ Supporting Equipment}

This equipment list and these drawings are preliminary in that they have not been checked for errors, and have no formal PNL approvals. They are not approved for construction of a complete reactor system. The equipment list is unfinished in terms of identifying all model numbers but is believed to be fairly complete otherwise. Identifying items in the table with those on the drawings is unfinished work. 


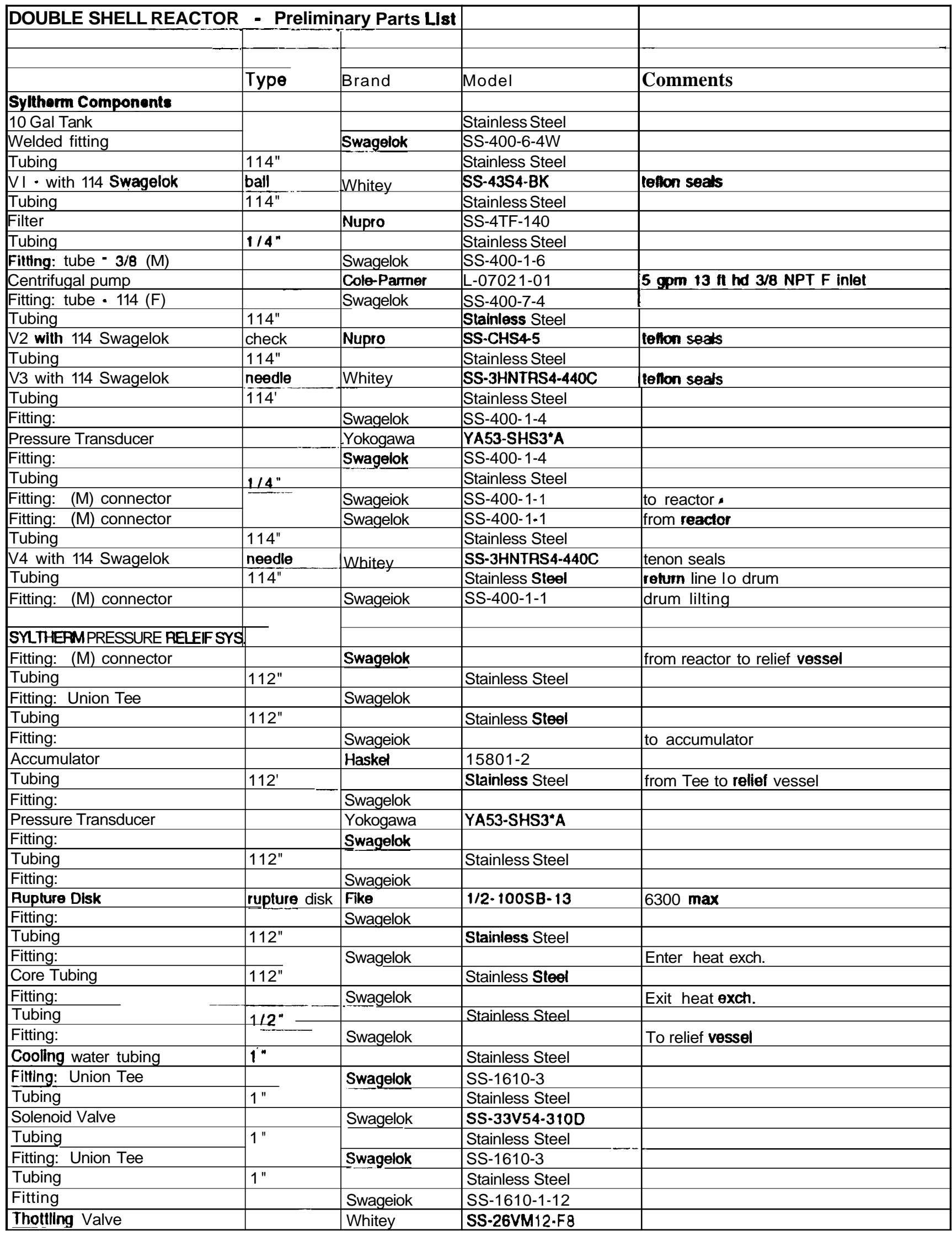




\begin{tabular}{|c|c|c|c|c|}
\hline Filting & & Swagelok & SS-1610-1-16 & \\
\hline Tubing & $1^{n}$ & & Stainless Steed & \\
\hline Fitting: Male Connector & & Swagelok & SS-1610-1-16 & Cooling $\mathrm{H} 2 \mathrm{O}$ enters \\
\hline Exchanger Shell & & Fabricated & & \\
\hline Fitting: Male Connector & & Swagelok & SS-1610-1-16 & Cooling $\mathrm{H} 2 \mathrm{O}$ exils \\
\hline Tubing & $1^{n}$ & & Stainless Steel & \\
\hline Thottling Valve & & Swagelok & & \\
\hline Sight Drain & & Ernst Gage & E-57-SS-4 & \\
\hline Cooling water tubing & $1^{n}$ & & Stainless Steed & \\
\hline Tubing & $1 / 4^{\prime \prime}$ & & Stainless Steel & \\
\hline Thermocouple fitting & & Swagelok & SS-200-R-4-BT & \\
\hline Thermocouple & Type K & Omega & TJ36-CAIN-18G-?? & Purchase quick disconnect plugs \\
\hline & & & & \\
\hline & & & & \\
\hline Organic Llquild Wasto Compo & $n+s$ & & & \\
\hline 50 Gal Tank & & & Stainless Steel & \\
\hline Welded fitting & & Swagelok & SS.400-6.4W & \\
\hline Tubing & $1 / 2^{n}$ & & Stainless Steel & \\
\hline Fitting & & Swagelok & & \\
\hline Filter & & McMaster & $4745 \mathrm{~K} 9$ & \\
\hline Fitting & & Swagelok & & \\
\hline V6 - with $1 / 4$ Swagelok & ball & Whitey & SS-45S8-BK & \\
\hline Tubing & $1 / 2^{\prime \prime}$ & & Stainless Steel & \\
\hline Filting: Reducer $1 / 4-1 / 2$ & & Swagelok & SS-400-R-B-BT & \\
\hline Fitting: Union Toe & & Swagelok & SS-810-3 & \\
\hline Thermocouple & Type $\bar{K}$ & Omega & TJ36-CAIN-14G-?? & Purchase quick disconnect plugs \\
\hline Tubing & $1 / 2$ & & Stainless Steel & \\
\hline V7 - with 1/4 Swagelok & check & Nupro & SS-BC-1 & \\
\hline Tubing & $1 / 2^{\prime \prime}$ & & Stainless Steol & \\
\hline Fitting: & & Swagelok & SS-810-1-8 & \\
\hline Liquid Pump & pneumatic & Haskel & $A W-60-C$ & \\
\hline Filting: & & Swagelok & SS-810-1-8 & SS-400-1-8 for $1 / 4$ fubing \\
\hline Tubing & $\sqrt{1 / 2 "}$ & & Stainless Steel & \\
\hline Fitting: & & Swagelok & SS-400-1-4 & \\
\hline High press. accumulator & & Haskel & $15801-2$ & \\
\hline Fitting: & & Swagelok & SS-400-1-4 & \\
\hline Tubing & $1 / 4$ & & Stainless Steol & \\
\hline V8 - with 1/4 Swagelok & needle & Whitey & SS-3HNTRS4-440C & \\
\hline Tubing & $1 / 4^{\prime \prime}$ & & Stainiess Steol & \\
\hline Fitting: Reducer $1 / 16 \cdot 1 / 4$ & & Swagelok & SS-100-R-4-BT & \\
\hline Fitting: Union Toe & & Swagelok & SS-400-3 & \\
\hline Thermocouple & Type K & Omega & TJ36-CAIN-116G-?? & Purchase quick disconnect plugs \\
\hline Tubing & $1 / 4^{n}$ & & Stainless Steel & \\
\hline Filling: & & Swagelok & \multicolumn{2}{|c|}{ SS-810-6-4 + SS-810-A-8ANF } \\
\hline Flow Sensor & & Omega & FTB502-1CK-5KP & $.025-.25 \mathrm{GPM}$ \\
\hline Fitting: & & Swagelok & \multicolumn{2}{|c|}{ SS-810-6-4 + SS-810-A-8ANF } \\
\hline Tubing & $1 / 4^{\prime \prime}$ & & Staintess Steel & \\
\hline Fitting: (F) Branch Tee & & Swagelok & SS-400-3-4TTF & \\
\hline Tubing & $1 / 4^{\prime \prime}$ & & Stainless Steel & \\
\hline Fitting: & & Swagelok & & \\
\hline rupture disk & & Fike & $1 / 2 \cdot 1005 B-13$ & 6300 max \\
\hline Fitling: & & & & \\
\hline Tubing & $1 / 4^{\prime \prime}$ & & Stainless Steel & 10 relief vessel \\
\hline Filting: & & Swagelok & SS.400-1.4 & Enter heat exch. \\
\hline Core Tubing & $1 / 4$ & & Stainless Steol & \\
\hline Fitting: & & Swagelok & SS.400-1.4 & Exit heat exch. \\
\hline Tubing & $1 / 4 "$ & & Stainless Sleel & \\
\hline Filting: & & Swagelok & SS.400-1.4 & To relief vessel \\
\hline Cooling water tubing & $1 "$ & & Stainless Sleol & \\
\hline Fitting: Union Toe & & Swagelok & SS.1610-3 & \\
\hline Tubing & $1 "$ & & Stainless Sleel & \\
\hline Solenoid Valve & & Swagelok & SS-33V54-310D & \\
\hline
\end{tabular}




\begin{tabular}{|c|c|c|c|c|}
\hline Tubing & $1^{*}$ & & Stainless Steet & \\
\hline Fitting: Union Tee & & Swagelok & SS.1610-3 & \\
\hline Tubing & $1 \%$ & & Stainless Steol & \\
\hline Filling & & Swagelok & SS. $1610-1-12$ & \\
\hline Thottling Vaive & & Whitey & SS-26VM12-F8 & \\
\hline Filling & & Swagelok & SS-1610-1-16 & \\
\hline Tubing & $1^{\prime \prime}$ & & Slainless Steel & \\
\hline Fitting: Male Conneclor & & Swagelok & SS-1610-1-16 & Cooling $\mathrm{H} 2 \mathrm{O}$ enters \\
\hline Exchanger Shell & & Fabricated & & \\
\hline Fitting: Male Conneclor & & Swagelok & SS-1610-1-16 & Cooling $\mathrm{H} 2 \mathrm{O}$ exils \\
\hline Tubing & 1 " & & Stainless Steol & \\
\hline \multicolumn{5}{|l|}{ Tholtling Valve } \\
\hline \multicolumn{5}{|l|}{ Sight Drain } \\
\hline Cooling water lubing & 11 & & Stainless Steol & \\
\hline Tubing & $1 / \sqrt{14}$ & & Stainless Steol & \\
\hline Thermocouple fitting & & Swagelok & $S S-200-4-8 T$ & \\
\hline Thermocouple & Type $\mathrm{K}$ & Omega & TJ36-CAIN-18G-?? & Purchase quick disconnect plugs \\
\hline Tubing & $1 / 4^{\prime \prime}$ & & Stainless Steel & From Union Tee belore rupture disk \\
\hline Fitting: (F) Branch Teo & & Swagelok & SS-400-3-4TTF & \\
\hline Tubing & $1 / 4^{n}$ & & Stainless Sted & to lecture boltle then accumulator \\
\hline Fitting & & Swagelok & SS-400-1-4 & \\
\hline Lecture Bottle & & Fabricate & & \\
\hline Filting & & Swagelok & SS-400-1-4 & \\
\hline Tubing & $1 / 4^{n}$ & & Stainless Steel & \\
\hline Filling & & Swagelok & & to accumulator \\
\hline Tubing & $1 / 4^{\prime \prime}$ & & Stainless Stoel & From union tee \\
\hline Filting: & & Swagelok & SS-400-1-4 & \\
\hline Pressure Transducer & & Yokogawa & YA53-SHS3*A & \\
\hline Fitting & & Swagelok & SS-400-1.4 & \\
\hline Tubing & 114 & & Stainless Steel & \\
\hline Fining: (M) connector & & Swagelok & SS-400-1.1 & to reactor \\
\hline & 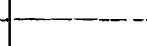 & & & \\
\hline \multicolumn{5}{|l|}{ Rellot Vessel Components } \\
\hline Vessel & & & Skinless Steel & \\
\hline N2 purge tubing & $114 "$ & & Stainless Steel & Pressurizing line \\
\hline \multicolumn{5}{|l|}{ Check Valve } \\
\hline Tubing & $114 "$ & & Stainless Steel & \\
\hline Fitting & & & & To vessel \\
\hline Fitting & & & & From vessel \\
\hline Tubing & $114 "$ & & Skinless Steel & Purge line \\
\hline \multicolumn{5}{|l|}{ Check Valve } \\
\hline Tubing & $114 "$ & & Skinless Steel & \\
\hline Tubing & $2 "$ & & Stainless Steel & Flush out line (in) \\
\hline \multicolumn{5}{|l|}{ Ball Valve } \\
\hline Tubing & $2 "$ & & Stainless Steel & \\
\hline Fitting & & & & To vessel \\
\hline Fitting & \multirow[b]{2}{*}{$2 "$} & & & Flush out line from vessel \\
\hline Tubing & & & Stainless Steel & \\
\hline \multicolumn{5}{|l|}{ Ball Valve } \\
\hline Tublng & $2 n$ & & Stainless Steel & \\
\hline Fitting & & & & Flush out line from vessel \\
\hline Tubing & $2 "$ & & Stainless Steel & \\
\hline \multicolumn{5}{|l|}{ Relief Valve } \\
\hline Tubing & $2 "$ & & Stainless Steel & \\
\hline & & & & \\
\hline \multicolumn{5}{|l|}{ Oxygen Components } \\
\hline & & & & \\
\hline Standard Oxygen Bottles & & From Stores & & \\
\hline Single regulator 2 header & Manifold & Rexarc & $3-04-431 \mathrm{G} / 12$ & 12 bottles of 02 \\
\hline Fitting & & Swagelok & & \\
\hline
\end{tabular}




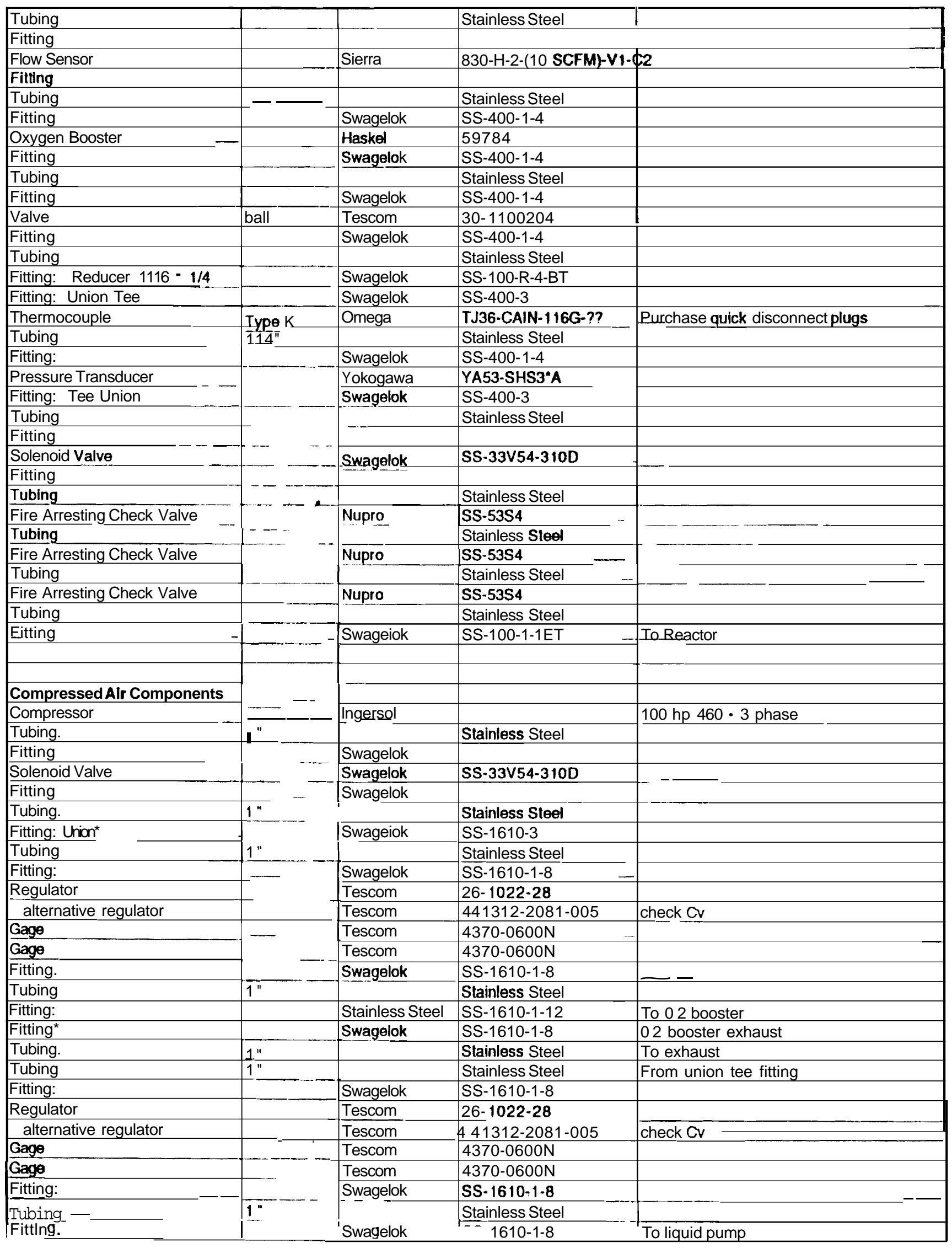




\begin{tabular}{|c|c|c|c|c|}
\hline Fitting: & & Swagelok & SS-1610-1-8 & Liquid pump exhaust \\
\hline Tubing: & $1 "$ & & Slainless Steel & To exhaust \\
\hline Aeactor Product Components & & & $54-2100$ series & \\
\hline Fitting: (M) connector & - & Swagelok & SS-400-1-1 & From reactor \\
\hline Tubing & $114 "$ & & Stainless Steel & \\
\hline Fitting: & & Swagelok & SS-400-1-4 & Enter heat exch. \\
\hline Cote Tubing & $114 "$ & & Stainless Steel & \\
\hline Fitting: & & Swagelok & SS-400-1-4 & Exit head exch \\
\hline Coollng water tubing & $1 "$ & & Stainless Steel & \\
\hline Ball Valve & & Swagelok & SS-65IS16 & \\
\hline \multicolumn{5}{|l|}{ Fitting: } \\
\hline \multicolumn{5}{|l|}{ Optical Flow Meter } \\
\hline \multicolumn{5}{|l|}{ Flttlng: } \\
\hline Fitting. Male Connector & & Swagelok & SS-1610-1-16 & Cooling H2O enters \\
\hline Exchanger Shell & & Fabricated & & \\
\hline Fitting. Male Connector & & Swagelok & SS-1610-1-16 & Cooling $\mathrm{H} 20$ exits \\
\hline Cooling water tubing & $1 "$ & & Slainless Sleel & \\
\hline \multicolumn{5}{|l|}{ Fitting: } \\
\hline Thottllng Valve & & Swagelok & & \\
\hline \multicolumn{5}{|l|}{ Fitting: } \\
\hline Tublng & & & Stainless Steel & \\
\hline \multicolumn{5}{|l|}{ Sight Drain } \\
\hline Tubing & $1 / 4^{\prime \prime}$ & & Stainless Steel & \\
\hline Fitting: & & Swagelok & SS-400--61 & Enter heat exch. \\
\hline Core Tubing & $1 / \overline{4}$ & & Stainless Steel & \\
\hline Fitting & & Swagelok & SS-400-1-4 & Exit head exch \\
\hline Cooling water tubing & $1 "$ & & Stainless Steel & \\
\hline \multicolumn{5}{|l|}{ Filting: } \\
\hline \multicolumn{5}{|l|}{ Ball Valve } \\
\hline \multicolumn{5}{|l|}{ Fitting: } \\
\hline \multicolumn{5}{|l|}{ Optical Flow Meter } \\
\hline \multicolumn{5}{|l|}{ Fitting. } \\
\hline Fitting: Male Connector & & Swagelok & SS-1610-1-16 & Cooling H2O enters \\
\hline Exchanger Shell & & Fabricated & & \\
\hline Fitting: Male Connector & & Swagelok & SS-1610-1-16 & Cooling $\mathrm{H} 2 \mathrm{O}$ exits \\
\hline Cooling water tubing & $1 "$ & & Stainless Steel & \\
\hline Tubing & $1 / 4^{n}$ & & Slainless Steel & \\
\hline Fitting: & & Swagelok & SS-400-1-4 & Enter heat exch \\
\hline Core Tubing & $1 / 4^{n}$ & & Stainless Steel & \\
\hline Fitting: & & Swagelok & SS-400-1-4 & Exit head exch. \\
\hline Cooling water tubing & $1 "$ & & & \\
\hline \multicolumn{5}{|l|}{ Fitting: } \\
\hline \multicolumn{5}{|l|}{ Ball Valve } \\
\hline \multicolumn{5}{|l|}{ Fitting: } \\
\hline \multicolumn{5}{|l|}{ Optical Flow Meter } \\
\hline \multicolumn{5}{|l|}{ Fitting: } \\
\hline \multicolumn{5}{|l|}{ Fitting: } \\
\hline Ball Valve & & & & \\
\hline Fitting. & & & & \\
\hline Optkal Flow Meter & & & & \\
\hline Fitting: & & & & \\
\hline Fitting: Male Connector & & Swagelok & SS-1610-1-16 & Cooling $\mathrm{H} 20$ enters \\
\hline Exchanger Shell & & Fabricate & & \\
\hline Fittlng: Male Connector & & Swagelok & SS-1610-1-16 & Cooling $\mathrm{H} 2 \mathrm{O}$ exits \\
\hline Cooling water tubing & $1 "$ & & Stainless Steel & \\
\hline Fittlng: & & & & \\
\hline Ball Valve & & & & \\
\hline Fitting: & & & & \\
\hline Oplical Flow Meter & & & & \\
\hline Flttlng: & & & & \\
\hline
\end{tabular}




\begin{tabular}{|c|c|c|c|c|}
\hline Tubing & $1 / 4^{\prime \prime}$ & & Stainless Steel & \\
\hline Fitting: Reducer 1116 - 1/4 & & Swagelok & SS-100-R-4-BT & \\
\hline Filling: Union Tee & & Swagelok & SS-400-3 & \\
\hline Thermocouple & Type K & Omega & TJ36-CAIN-116G-?? & Purchase quick disconnect plugs \\
\hline Tubing & $114 "$ & & Stainless Steel & \\
\hline Fitting: & & Swagelok & SS-400-1-4 & \\
\hline Pressure Transducer & & Yokogawa & YA53-SHS3*A & \\
\hline Fitting: & & Swagelok & SS-400-1-4 & \\
\hline$\sqrt{18}$ & back press. & Tescom & 54-2325T212A & 150F 5000 psi \\
\hline Fitting: Male Connector & & Swagelok & SS-400-1-12 & \\
\hline Tubing & 114" & & Stainless Steel & \\
\hline Fitting: & & & & \\
\hline Seperalion Bottle & & Eabricated & Stainless Steel & \\
\hline Pressure relief valve & press relief & Nupro & SS-4A3A1-B & teflon seals \\
\hline Tubing to vent & 1,14 & & Stainless Steel & \\
\hline \multicolumn{5}{|l|}{ Fitting: } \\
\hline Tubing & \multirow[t]{2}{*}{$114 "$} & & Stainless Steel & \\
\hline Fitting. Reducer $1116 \cdot \mathbf{1 / 4}$ & & Swagelok & SS-100-R-4-BT & \\
\hline Filling. Union Tee & - & Swagelok & SS-400-3 & \\
\hline Thermocouple & & Omega & TJ36-CAIN-116G-?? & Purchase quick disconnect plugs \\
\hline Tubing & \multirow[t]{2}{*}{$114 "$} & & Stainless Steel & \\
\hline Fitting: & & Swagelok & SS-400-1-4 & \\
\hline Flow Sensor & & Sierra & $760-N 1$ & \\
\hline Fitting: & \multirow{4}{*}{ 1114" } & Swagelok & SS-400-1-4 & \\
\hline Tubing & & & Stainless Steel & \\
\hline Fitting: & & Swagelok & SS-400-1-4 & \multirow{2}{*}{-} \\
\hline Pressure Transducer & & Yokogawa & YA53-SHS3*A & \\
\hline Fitting: & & Swagelok & SS-400-1-4 & \\
\hline Tubing & \multirow{3}{*}{ - } & & Stainless Steel & \\
\hline Fitting: Union Tee & & \multirow[t]{2}{*}{ Swagelok } & SS-400-3 & \\
\hline Tubing & & & Stainless Steel & \\
\hline V19 - with 114 Swagelok & \multirow{4}{*}{$\begin{array}{l}\frac{\text { ball }}{114 "} \\
114 "\end{array}$} & \multirow{2}{*}{ Whitey } & SS-43S4 & \\
\hline Tubing & & & Stainless Steel & \\
\hline Fitting: & & & & To vent \\
\hline Tubing & & & Stainless Steel & \\
\hline V19 - with $1 / 4$ Swageiok & ball. & Whitey & SS-43S4 & \\
\hline Tubing _ & $114^{\pi}$ & & Stainless Steel & \\
\hline \multicolumn{5}{|l|}{ FittIng: } \\
\hline \multicolumn{5}{|l|}{ Filter } \\
\hline \multicolumn{5}{|l|}{ Fitting: } \\
\hline Tubing & $114 "$ & & Slainless Steel & \\
\hline Filling: & - & & & To GC \\
\hline \multicolumn{5}{|l|}{ Fitting: } \\
\hline Tubing & 114" & & Slainless Steel & \\
\hline Fitting: $\quad$ Reducer 1/16 - 1/4 & \multirow{2}{*}{$-\cdots$} & Swagelok & SS-100-R-4-BT & \multirow{2}{*}{$-\ldots-\ldots$} \\
\hline Filting: Union Tee & & Swagelok & SS-400-3 & \\
\hline Thermocouple & \multirow{2}{*}{ Type K } & Omega & f $36=64 \mathbb{N}=1166=33$ & $\overline{\text { Purchase quick disconnect plugs }}$ \\
\hline Tubing & & & Stainless Steel -- & \\
\hline Fitting: & & \& & SS-400-1-8 - & \\
\hline Flow Sensor & - & Sierra & $730-N 2-2-901 M$ & \\
\hline Fitting: & {$[-1$} & Swagelok & SS-400-1-8 & \\
\hline Tubing & $1 / 4^{11}$ & & Stainless Steel & \\
\hline Fitting: & - & Swagelok & SS-400-1-4 & \\
\hline Pressure Transducer & - & Yokogawa & YA53-SHS3*A & \\
\hline Fitting: & & Swagelok & SS $-400-1-4$ & \\
\hline Tubing & 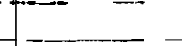 & & Stainless Steel & \\
\hline Fitting: Union Tee & & Swagelok & SS-400-3 & \\
\hline Tubing & $114 " \ldots$ & & Stainless Steel & \\
\hline V19-with 114 Swagelok & ball & Whitey & SS-43S4 & \\
\hline Tubing & $114 "$ & & Stainless Steel & \\
\hline
\end{tabular}




\begin{tabular}{|l|l|l|l|l|}
\hline Fitting: & & & to drain \\
\hline Tublng & $114 "$ & & \\
\hline V19 - with 114 Swagelok & ball & Whitey & SS-43S4 & \\
\hline Tubing & $114 "$ & & Stainless Steel & \\
\hline Fitting: & & & & \\
\hline Filter & & & & \\
\hline Fitting: & $114 "$ & & & \\
\hline Tubing & & Stainless Steel & to sampler \\
\hline Fitting: & & & \\
\hline
\end{tabular}




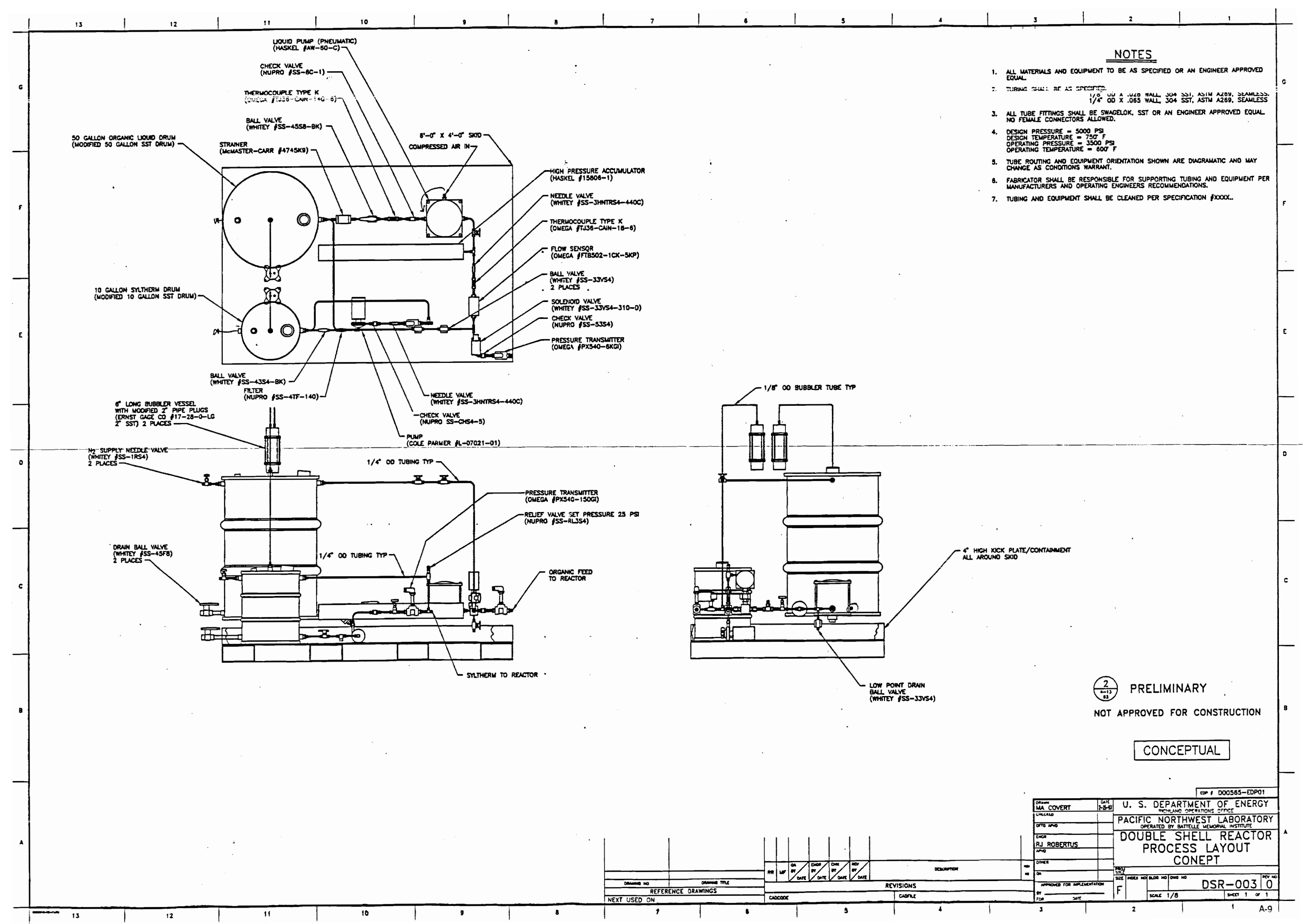




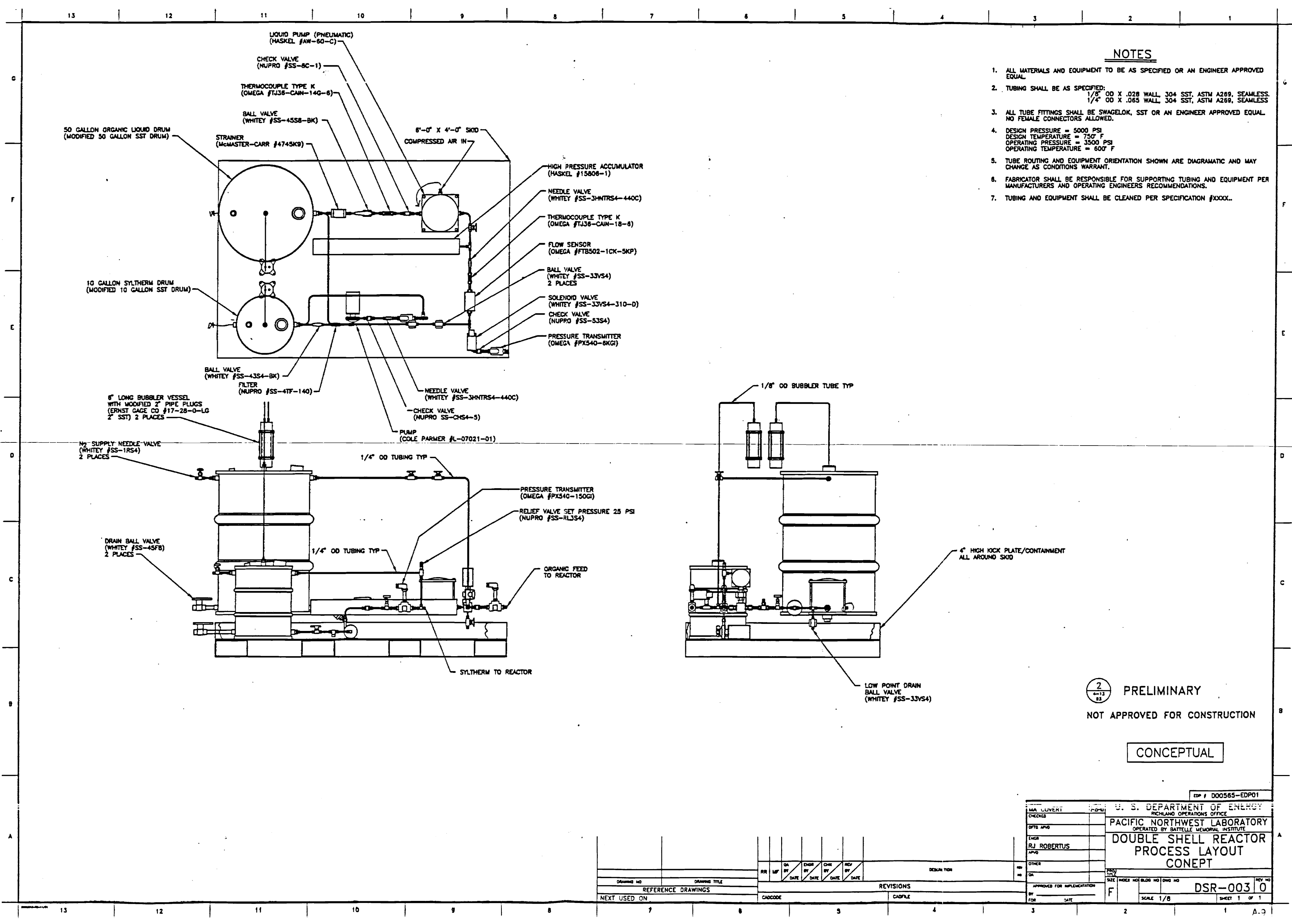




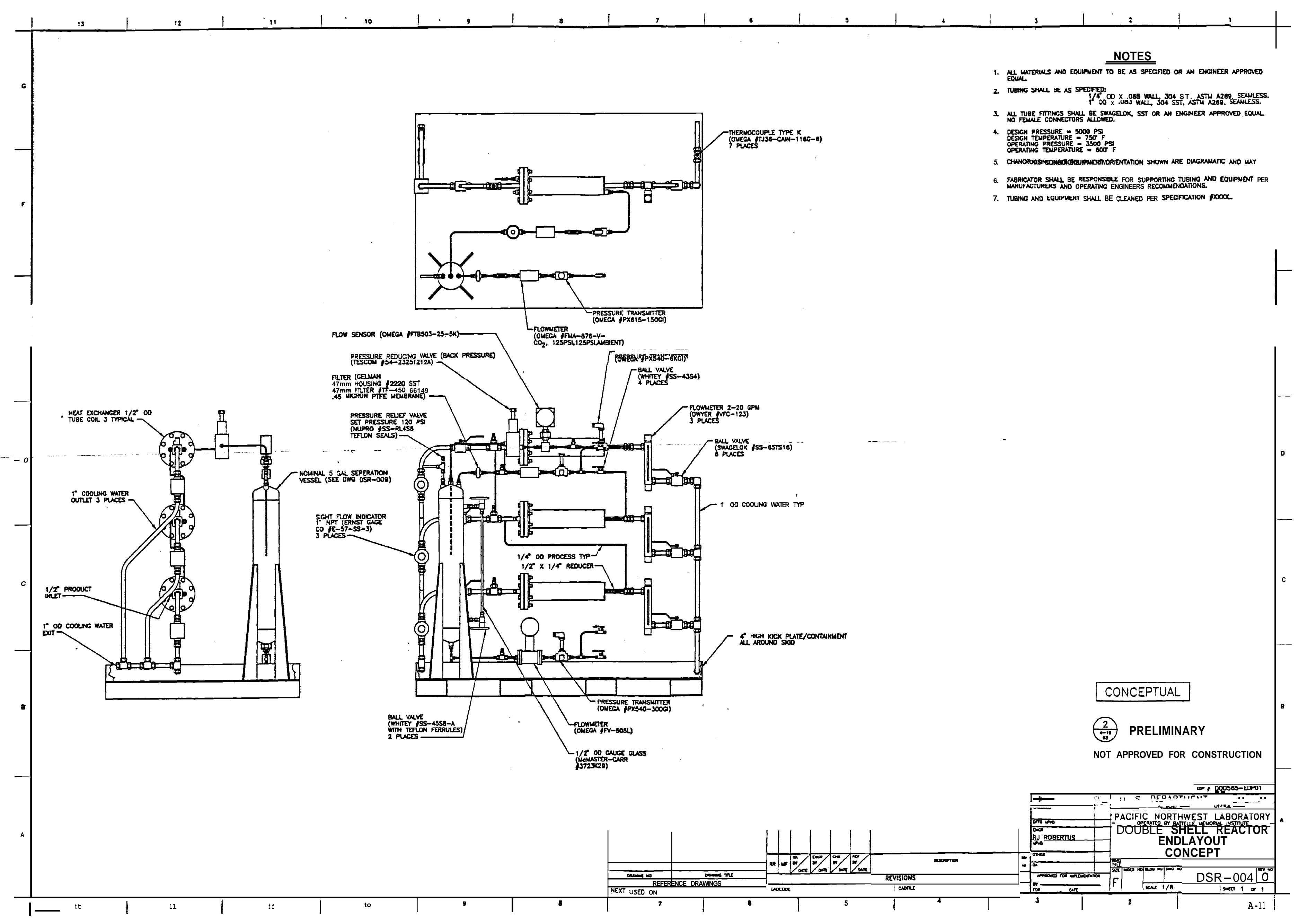




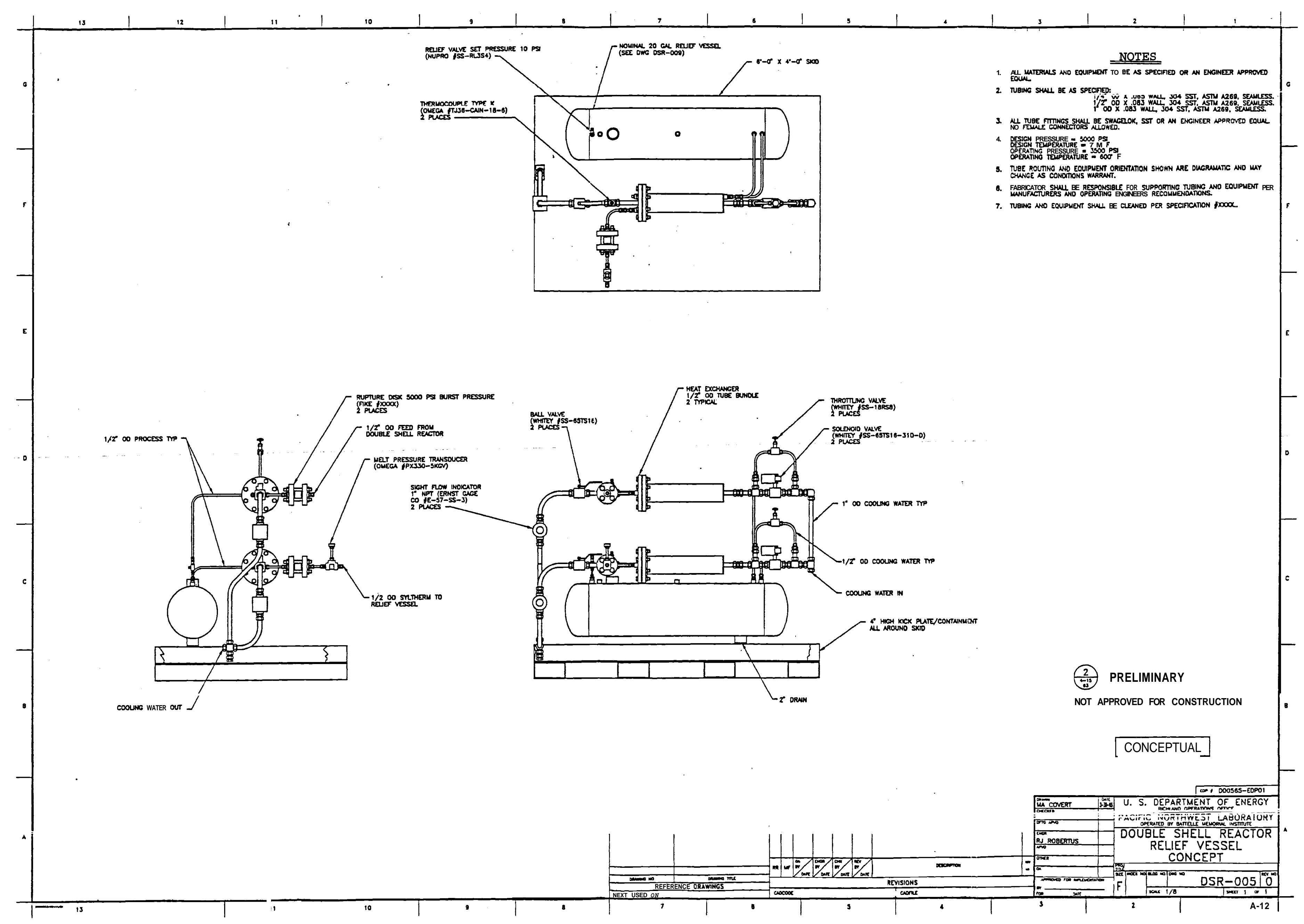




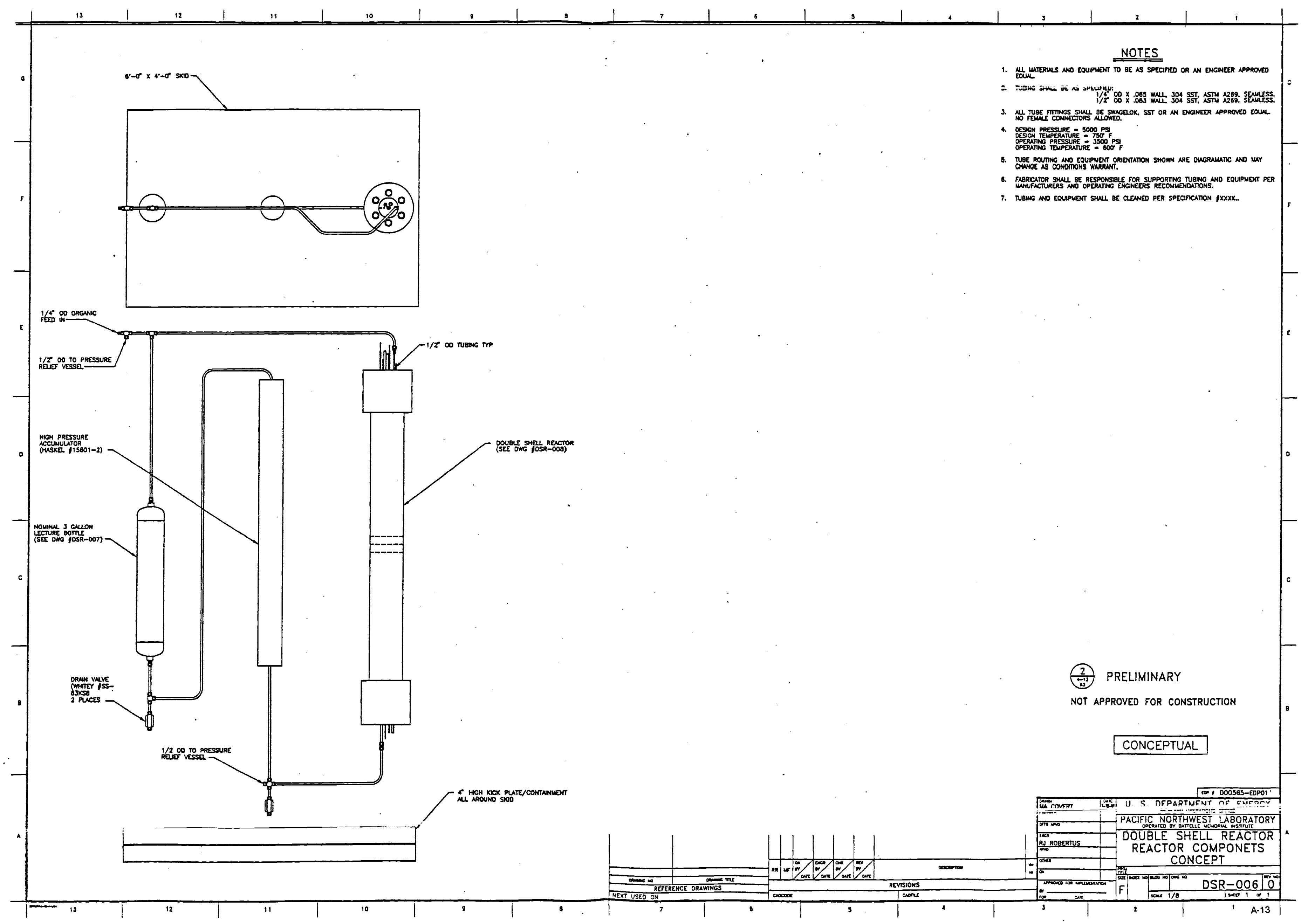




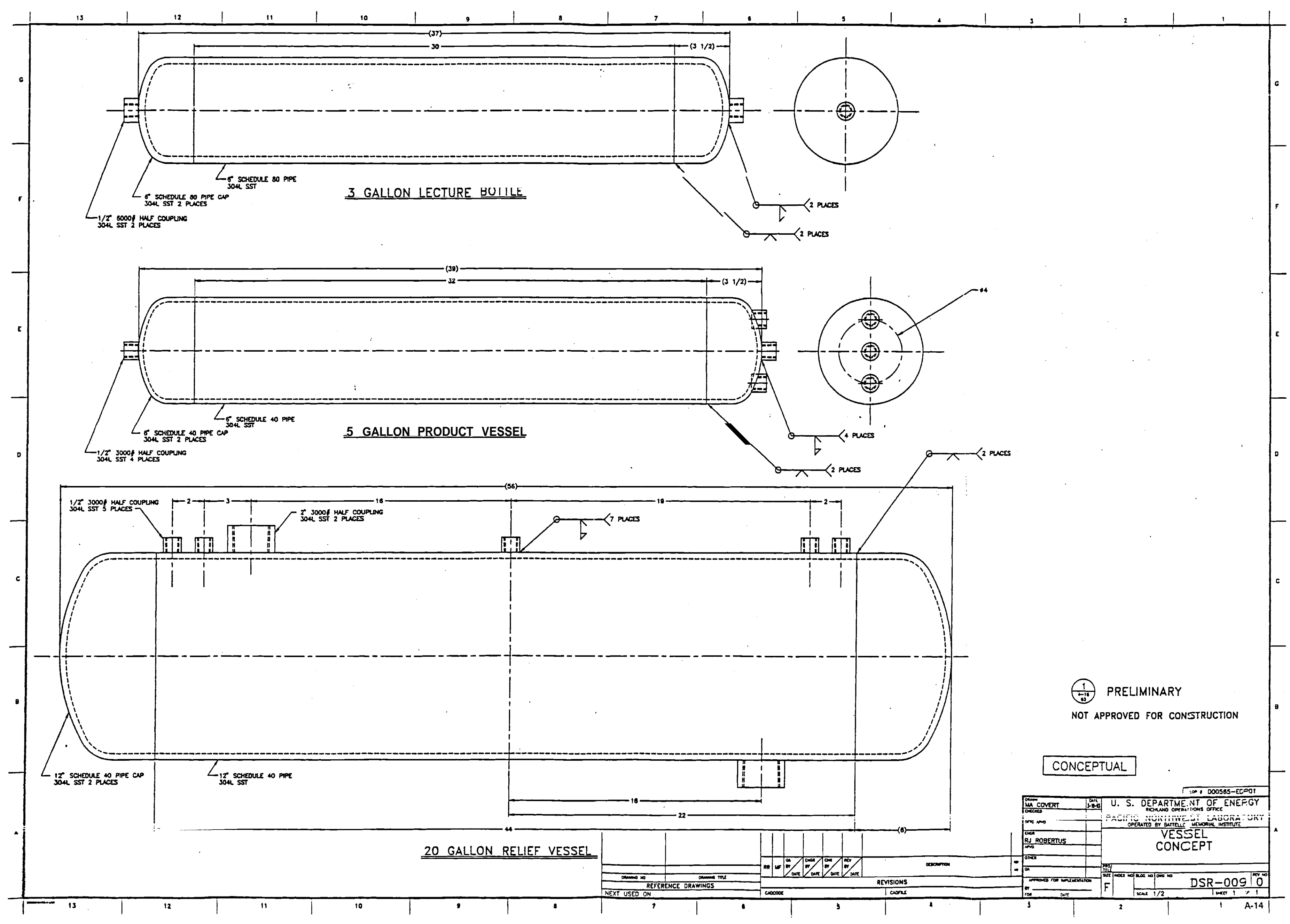




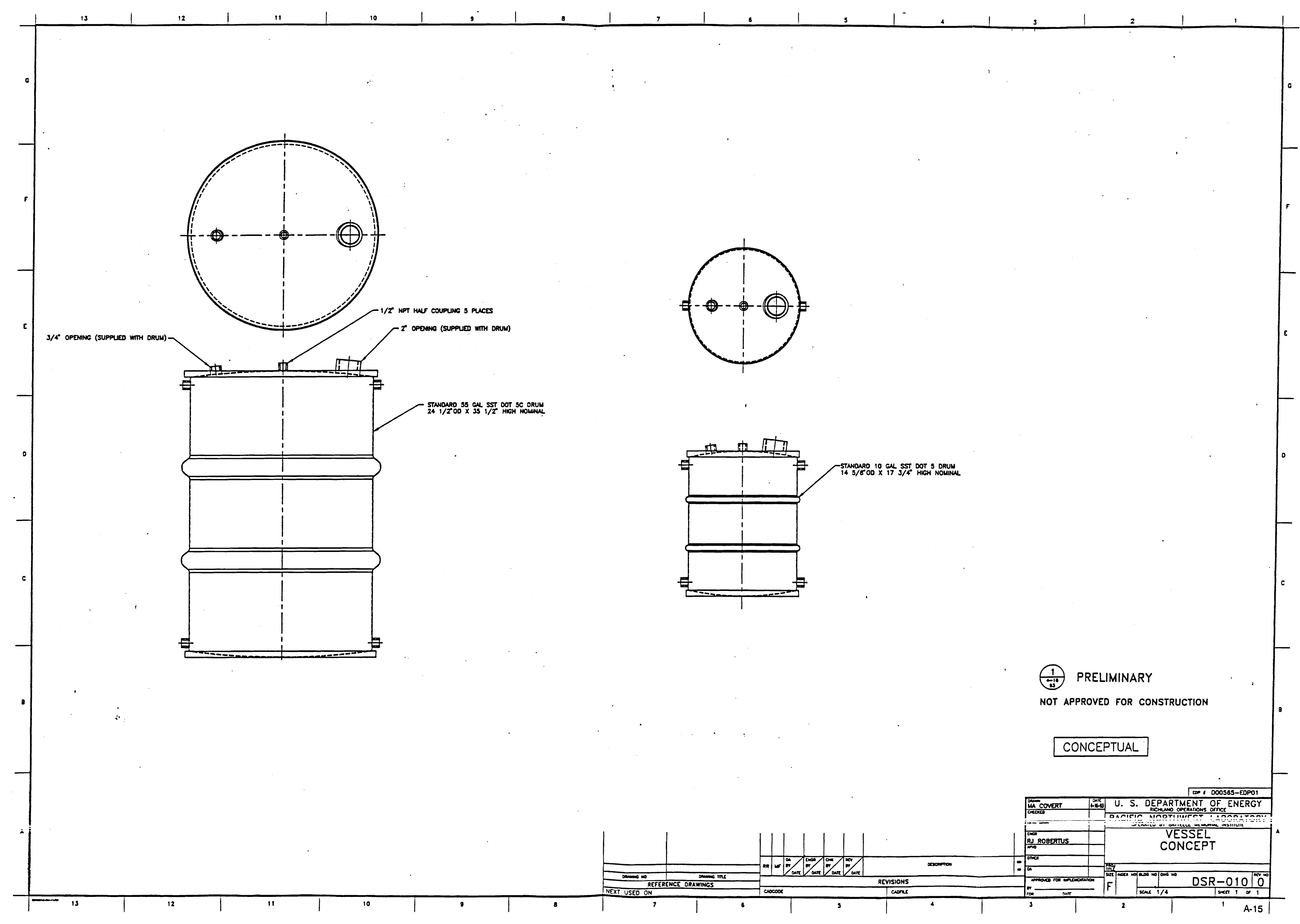




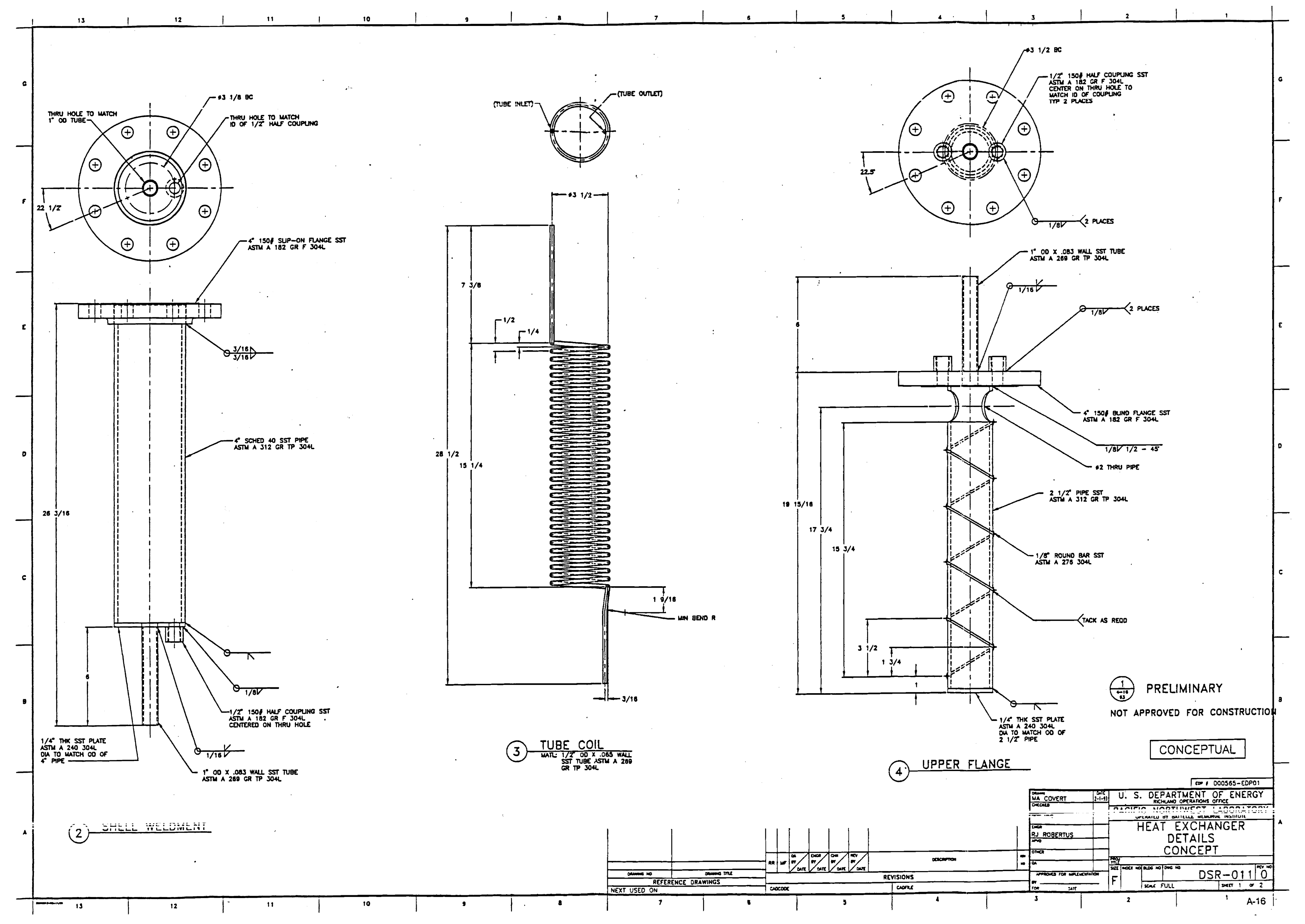




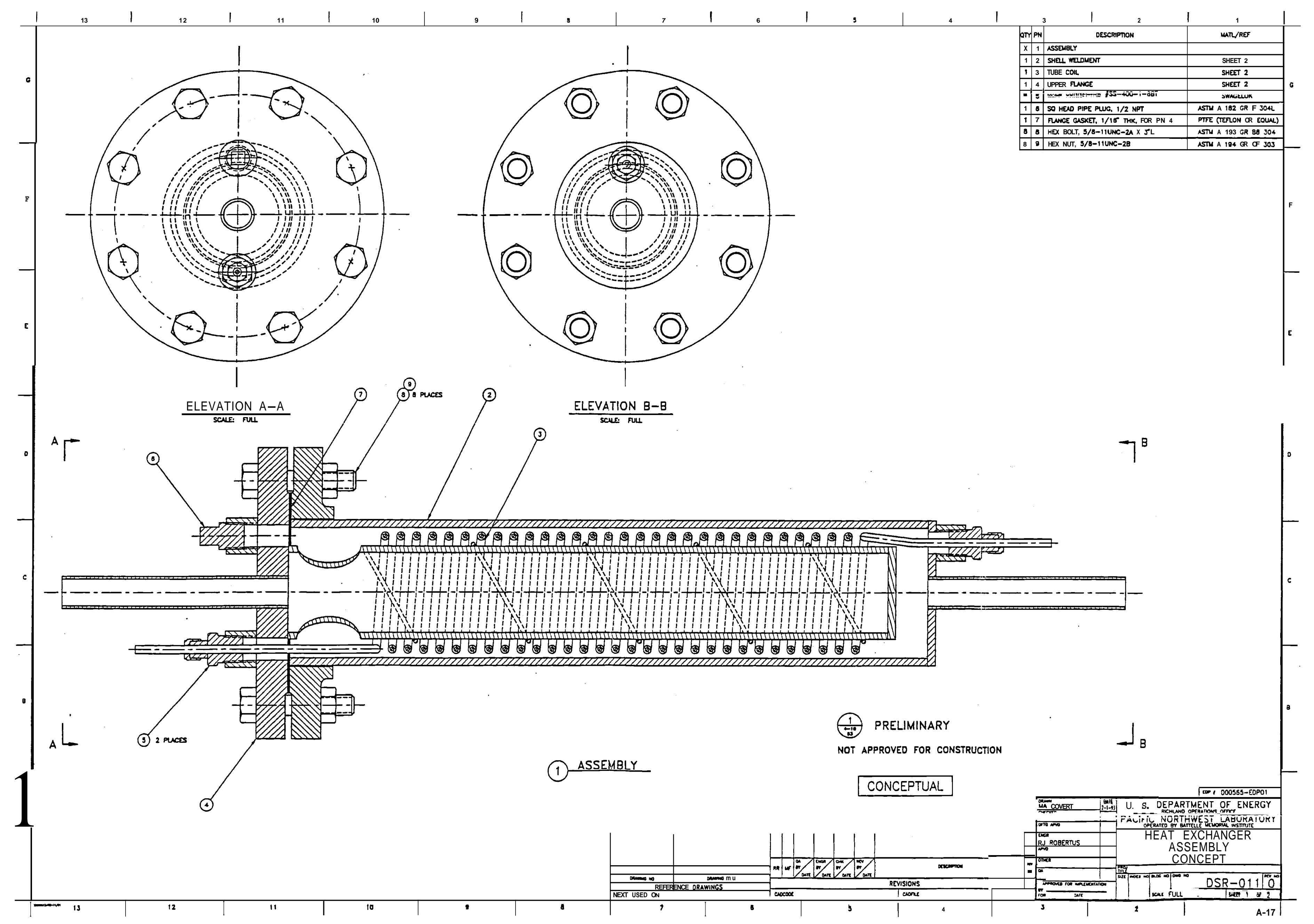



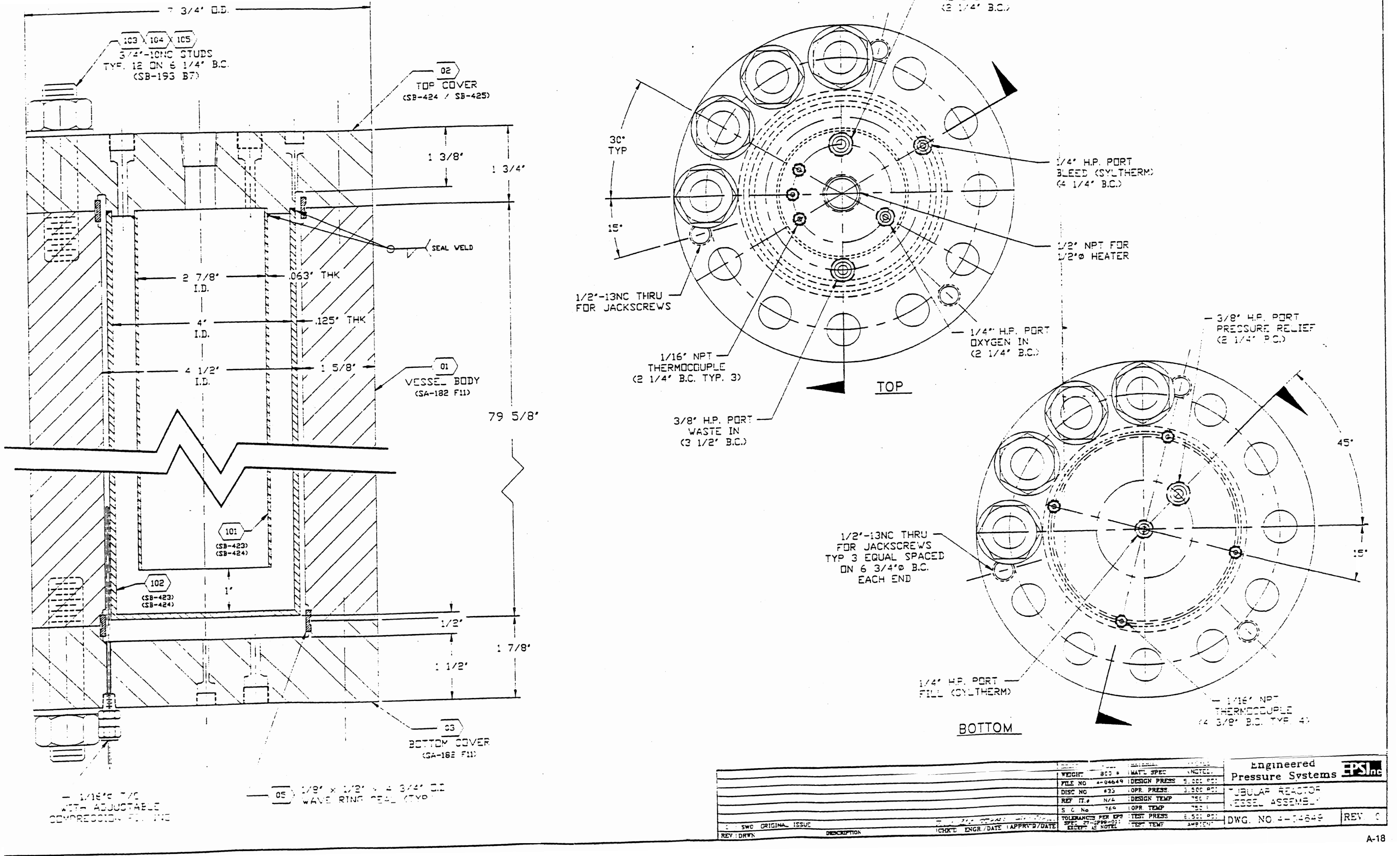